\title{
Factors of Changes in Waste Management in a Mountain Region of Southern Poland
}

\author{
Grzegorz Przydatek \\ 1 Engineering Institute, State University w Nowy Sącz, ul. Zamenhofa 1a, 33-300 Nowy Sącz, Poland \\ e-mail: gprzydatek@pwsz-ns.edu.pl
}

\begin{abstract}
The aim of the work was to analyse the changes in the effectiveness of municipal waste management for the period 2009-2015, in one of the largest counties in the mountainous region of southern Poland. Socio-demographic factors, as well as changes as a result of the implementation of the provisions of Directive 1999/31/WE and Directive 2008/98/EC into Polish legislation, are considered. Over the period of seven years, there was a significant increase in the amount of municipal waste generated in the county of $32 \%$, with a simultaneous increase in the number of inhabitants and a decrease in the number of individuals registered as unemployed. An increase in the amount of waste that is non-selectively collected and the number of properties covered by collections of municipal waste occurred before there were any changes in waste management. However, after the changes, the amount of six types of waste selectively collected (paper and cardboard, plastic, metal, bulky, WEEE) increased, with a significant $40 \%$ share of glass waste reference to the selectively collected waste. This may result from the changes in waste management. However, over the whole research period, more than $80 \%$ of waste was non-selectively collected, which may result from a lack of ecological awareness.
\end{abstract}

Keywords: waste management, selectively collected, socio-demographic factors, non-selectively collected, waste accumulation rate

\section{INTRODUCTION}

On a global scale, it is important that all waste producers are covered by organized waste collection. The management of municipal solid waste is one of the tasks of local authorities in each country (Faroog and Meraj, 2016), as a result of which the local authorities require waste compositional information at the local level to plan, implement and monitor the waste management schemes that will enable them to meet their contribution to the national targets (Burnley, 2007).

Solid municipal waste (MSW) poses a huge challenge to local governments due to its continuous growth (Buenrostro and Bocco, 2001). Since mid-2013, local governments in Poland, in accordance with the implementation of Directive 1999/31/WE (WE L 182 16.07.1999) and Directive 2008/98/EC (L 312 22.11.2008), have been obliged to implement Polish law to prevent the generation of MSW as far as is practicable.
They have also been required to increase the rate of waste recovery "at source" (Boas-Berg et al., 2018). While applying the waste hierarchy, European Union member states adopt the measures to encourage solutions that yield the best environmental impact (Pomberger et al., 2017) to help protect natural resources and prevent environmental degradation (Gharfalkar et al., 2015). The need to both limit the amount of waste generated and to increase the levels of recovery requires selective collection in various settlement units.

The number of investigations conducted to identify the factors affecting the production of waste generated is increasing and includes those conducted by Hekkert et al. (2008), Burnley (2007), Miliute-Plepiene and Plepys (2015), Talalaj and Walery (2015) and Liikanen et al. (2016). In the area of waste management, the mass accumulation of waste is determined based on rates. The data on waste accumulation per capita are widely used to compare the intensity of MSW 
generation in various locations (Kaseva and Moirana, 2010; Özbay, 2015). The accumulation of waste in the environment raises social awareness due to the problems caused by its growth (Mitsakas et al., 2017), including its further management. In addition to these rates, the studies that take into account socio-economic factors are becoming more frequent (Philippe and Culot, 2009), because waste is a social, ecological and often aesthetic problem. Guerrero et al. (2013) considered that the factors influencing the efficiency of waste management include the environmental, socio-cultural and institutional factors. Other factors influencing the amount of waste generated are the number of inhabitants, as well as the level of professional qualifications of the residents (Buenrostro and Bocco, 2001; Noori et al., 2009). Moreover, the type of residential housing, as well as local infrastructure, are considered as important factors in shaping the composition of waste (Den Boer et al., 2010), in addition to the geographical location. Other socio-demographic factors which are not directly related to waste management, such as number of registered unemployed or internal and external migration, may also be analysed.

The aim of this work was to analyse the efficiency of the changes in municipal waste management for the period 2009-2015, in one of the largest counties in the Malopolska Voivodeship in southern Poland, considering socio-demographic factors.

\section{MATERIALS AND METHODS}

The analysis involved the use of qualitative and quantitative data regarding the municipal waste generated in the county, divided into selectively collected (paper and cardboard, glass, plastics, metal, bulky and WEEE) and non-selectively collected waste. An element of statistics at study was average, minimum and maximum. A similar content of test waste was reported in Guerrero et al. (2013); however, these authors did not take organic waste production into account. The research material was annual data for the years 2009-2015 obtained on the basis of a questionnaire addressed to twelve municipalities in the Limanowa County, including: the amount of collected selectively collected waste based on six types and non-selectively collected waste; the number of inhabitants; and properties covered by the collection of municipal waste (including uninhabited).
Statistics Poland (2009-2016) were also used, including the value of the number of registered unemployed, internal and external migration within the Limanowa County and the results of field observations related to the collection and disposal of waste.

The data for the mass of waste used in the work for the period 2009-2015, which came from individual communes, comprised approximately 25 data points for each. On this basis, the results representative for the entire county were elaborated and the rates for the mass accumulation of municipal waste, including selectivity, and divided into year and day, were defined. The rates of waste accumulation per capita in tests were also used by Talalaj and Walery (2015). The study refers to Directive 2008/98 / EC according to which selective collection is required, which should include at least waste of paper and cardboard, metal, plastic and glass.

\section{Characteristic of the county}

The Limanowa County, with an area of $952 \mathrm{~km}^{2}$, is located in Southern Poland in the Malopolska

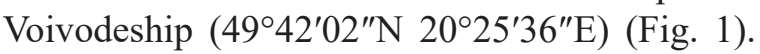
From the west, it borders with Myślenice County, from the north with the Bochnia and Brzesko Counties, from the east with Nowy Sącz County and from the south with Nowy Targ County. The county consists of 12 communes: Limanowa and Mszana Dolna (urban), Niedźwiedź, Dobra, Jodłownik, Laskowa, Kamienica, Limanowa, Mszana Dola, Łukowica, Słopnice, Tymbark including 171 villages and 91 small villages.

The county is the sixth largest in the Małopolskie Voivodship and ranked one hundred and forty-two for size in Poland. The county is dominated by industry and construction $(55.1 \%)$. The lowest share is $(1.1 \%)$ for agriculture, forestry, hunting and fishing in the presence of two cities in this area (2009-2016). The Limanowa County is a typically mountainous region at $400-580 \mathrm{~m}$ asl and is located in the Western Carpathians. The greater part of this area is occupied by the Beskid Wyspowy Subunit, while the southern part includes the northern slopes of the Gorce Mountains and the Gorce National Park, which are almost entirely within the county. Low single-family detached (dispersed) housing dominates in this area with the exception of the Limanowa and Mszana Dolna communes. Here, in addition, there are compact urban and high multi-family buildings. 


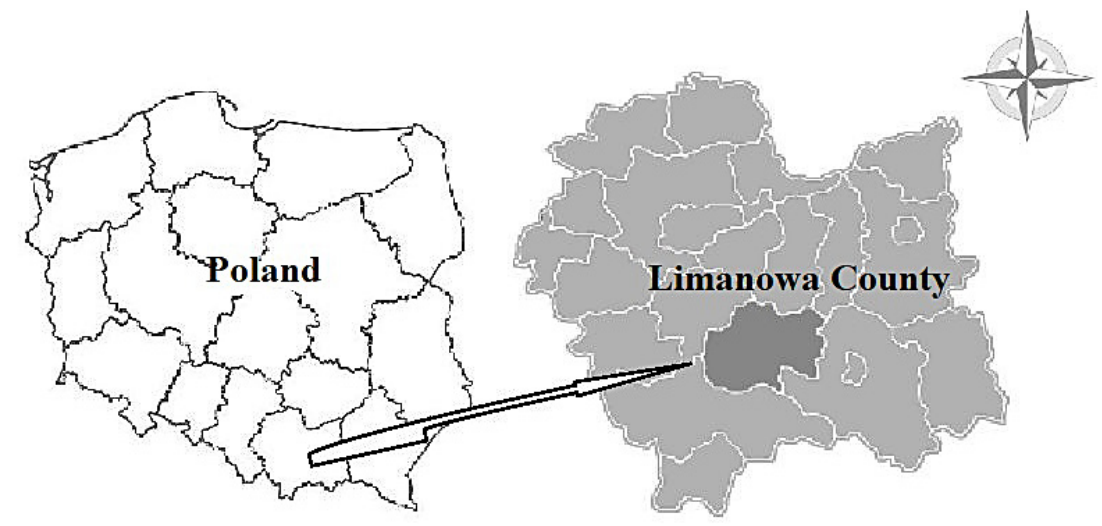

Figure 1. Location of Limanowa County in the Małopolska Voivodship (southern Poland)

\section{Waste management}

Municipalities and waste disposal companies are the key elements for waste management efficiency in the Limanowa County in the collection and transport of municipal solid waste. In general, municipalities are responsible for the collection and transportation of waste to recovery and disposal sites. After the system changes in waste management in 2013, all inhabitants in Poland and the county were covered by waste collection. Effective waste recovery was required for recycling and the choice of transport company was based on a tender procedure (Przydatek et al., 2017). Exports of waste collected in both selective non-selective ways in 7 year from the communes within the county took place once or twice a month. The increased frequency of reception was related to the spring and summer periods. The waste was collected in plastic bags as well as in containers (Table 1). The containers were used in larger population centres (cities) and in public places. Burnley (2007) suggested that even the type of container has an influence on municipal waste collection. De Oliveira Simonetto and Borenstein (2009) determined that the waste collection strategies represent a major issue in an environmentally efficient system, since they can significantly affect the recycling targets.
The wastes collected selectively and nonselectively in the Limanowa County were delivered to the waste disposal installation in the Małopolska Voivodeship area.

\section{RESULTS}

\section{Inhabitants and migration}

The number of inhabitants in the county in 2009-2015 demonstrated a positive increase of 5,045 (which is $4 \%$ ) with an average of 127.394 . Both the lowest $(124,278)$ and the largest $(129,323)$ rise in number of inhabitants occurred in two extreme years (Fig. 2).

The internal migration was within the range of 935-958 persons, with an average of 968, and external migration varied between 903 and 992 with an average of 991 . The lowest results for the internal and external migration of the county inhabitants occurred in 2009 and 2014, amounting to 935 and 903 respectively, and the highest results were 1,021 and 1,104. In 2014-2015, there was a decrease in the internal and external migration by almost 200 people in the studied area. The results for the internal migration showed an increase of 23 people and the external one by 89 people. The average results for the external and

Table 1. Solution for selectively and non-selectively collected municipal solid waste

\begin{tabular}{|c|c|c|c|c|c|c|c|}
\hline \multicolumn{2}{|c|}{ Frequency of waste reception } & \multicolumn{5}{|c|}{ Waste collecting devices } & \\
\hline \multicolumn{2}{|c|}{ (month) } & \multicolumn{2}{|c|}{ bag } & \multicolumn{2}{|c|}{ bin } & \multicolumn{2}{|c|}{ container } \\
\hline $\mathrm{n}-\mathrm{s}$ & $\mathrm{s}$ & $n-s$ & s & n-s & $\mathrm{s}$ & $\mathrm{n}-\mathrm{s}$ & $\mathrm{s}$ \\
\hline once - twice (spring,summer) & once - twice(spring,summer) & $x(r, t)$ & $x(r, t)$ & $x(t)$ & - & $x(r, t)$ & $x(t)$ \\
\hline
\end{tabular}

$\mathrm{n}-\mathrm{s}$ - non-selectively, $\mathrm{s}$ - selectively, $\mathrm{r}$ - rural, $\mathrm{t}-$ town 


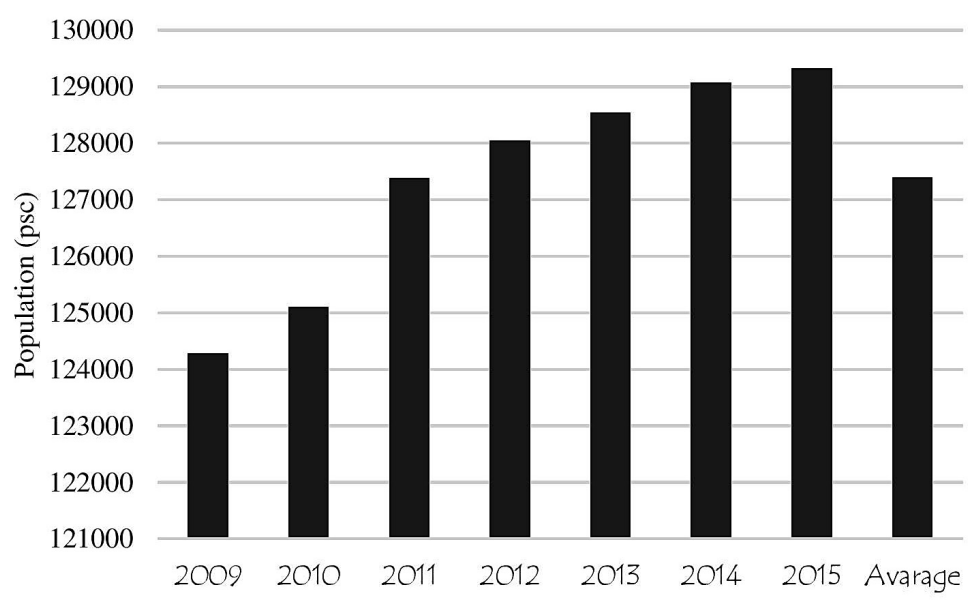

Figure 2. Number of inhabitants in the county in different years

internal migration rates, as well as their difference by 23 people, were found in the external advantage (Fig. 3).

\section{Registered unemployed}

A significant increase in registered unemployment, by 1,679 people, occurred in the country in 2009-2013 (which represents 19\%). In turn, between 2013 and 2015, a significant decrease of 3,020 people is noticeable. The highest unemployment rate was in 2013, at 10,569, while the lowest, at 7,549, occurred in 2015 with an average of 9,421 .1. In 7 years, registered unemployment fell in this area by 1,341 (which is $15 \%$ ) (Fig. 4).

\section{Residential buildings covered by collection of municipal waste}

The number of properties covered by the collection of municipal waste concerned both residential and uninhabited buildings, including public facilities. In 2009, the number of properties from which municipal waste was collected was the lowest and amounted to 20,188, with the highest occurring in 2012 at 33,670 with an average of 25,701. In 2013-2015, there was a decrease in the number of real properties covered by waste collection by 1,111 . Despite such a change, there was a general increase in the number of real estate properties by 10,634 , from which municipal waste were regularly collected (Fig.5).

\section{Waste collected selectively and non-selectively}

In the initial research period of 2009-2011, there was a decline in the amount of municipal waste collected both selectively and non-selectively. These declines amounted to $210 \mathrm{Mg}$ and $3.431 \mathrm{Mg}$, respectively. Between the consecutive years of 2012-2015, a dynamic increase in the

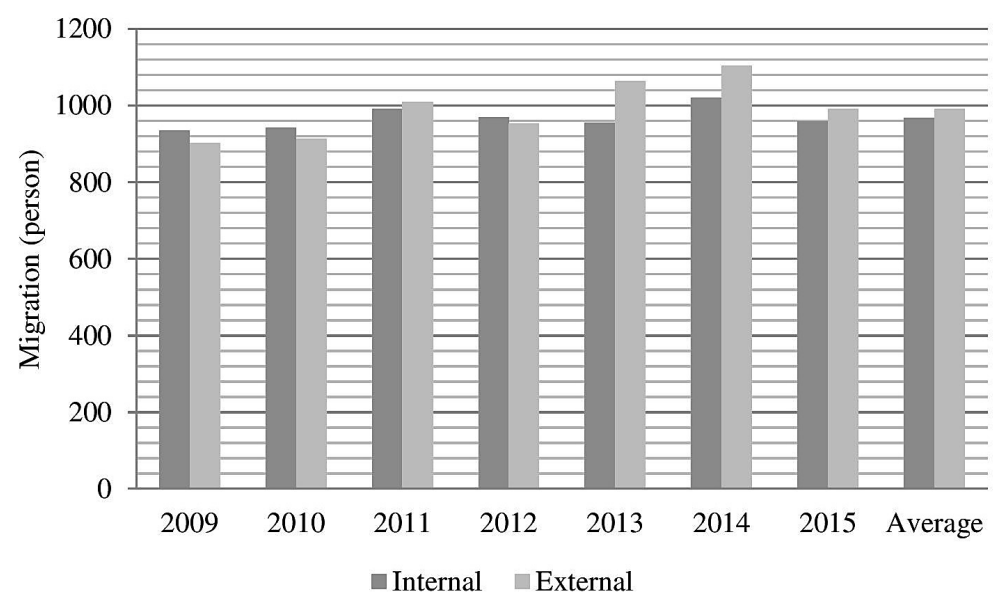

Figure 3. Number of inhabitants in the county in different years 


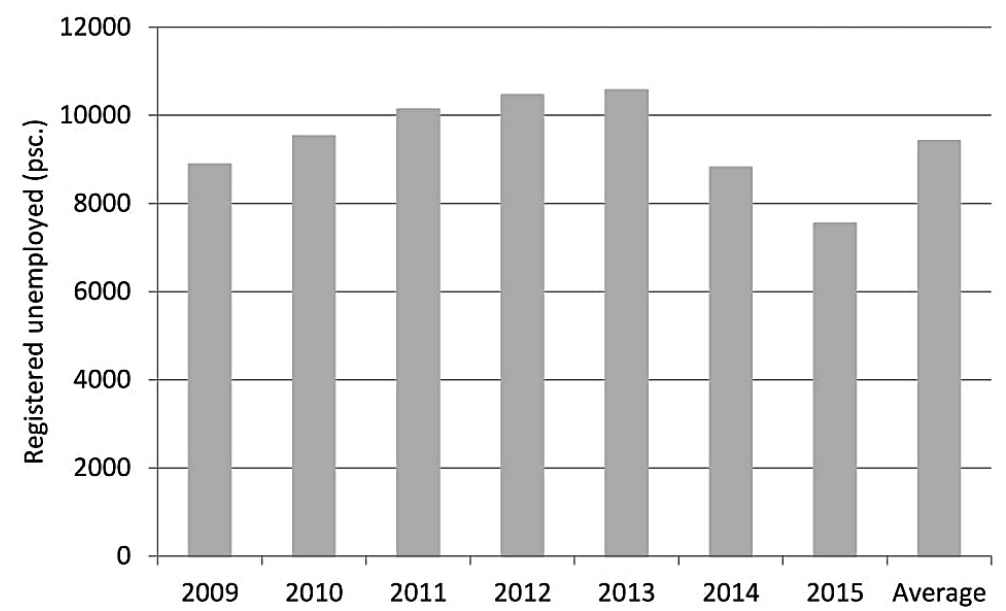

Figure 4. Registered unemployment in the Limanowa County

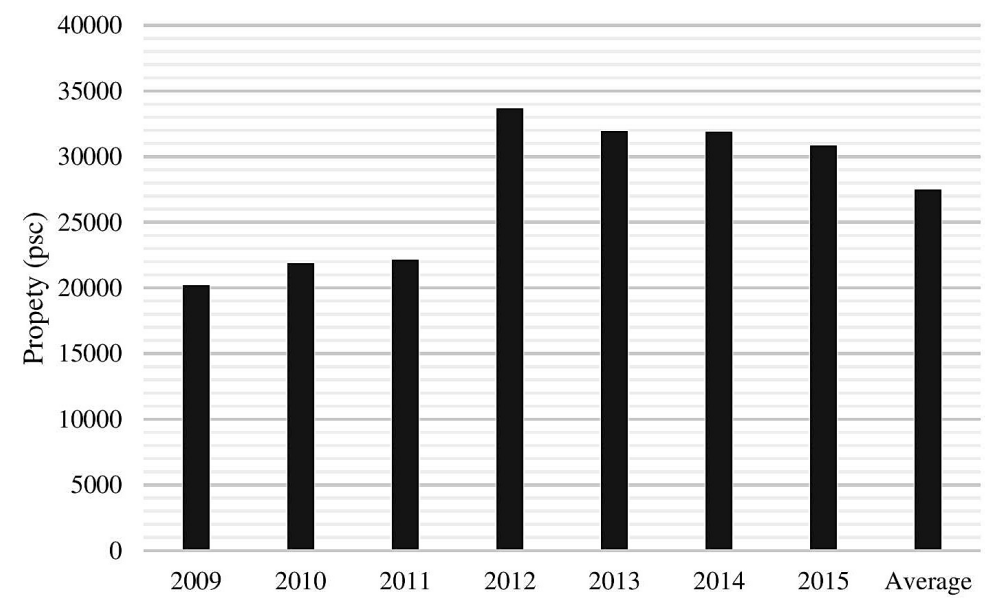

Figure 5. Number of properties covered by waste collection in different years

value of waste selectively collected by $2,141 \mathrm{Mg}$ is noticeable, as well as a decrease in that non-selective collected by $2,185 \mathrm{Mg}$. Within seven years, there was an increase in the mass of collected waste by $3,231 \mathrm{Mg}$ (which is $32 \%$ ), including the selectively collected waste in the amount of 2,185 $\mathrm{Mg}$. In the case of waste collected non-selectively there was a decrease by $503.9 \mathrm{Mg}$. These favourable results may be affected by the changes in the municipal waste management system caused by the implementation of the provisions of Directive 2008/98 / EC into Polish legislation, which have been in force since 2013 (Przydatek et al., 2017). The lowest amounts of waste collected in the county were observed simultaneously in the third analysed year, while the highest occurred in the fourth year in the case of non-selectively collected waste $(12,103.6 \mathrm{Mg})$ and the total mass of waste $(13,404.7 \mathrm{Mg})$. The largest amount of waste $(3,602 \mathrm{Mg})$ was selectively collected in 2014, after the changes (Fig.6).
Figure 7 shows the amount of waste collected selectively divided into six fractions. The mass of paper and cardboard waste collected in 2014 increased by $216 \mathrm{Mg}$ in comparison to 2009 . A noticeable decrease occurred in 2011 by 58 $\mathrm{Mg}$ in relation to the reference year and in 2015 by $108 \mathrm{Mg}$ in relation to the previous year. The latter value was the same as the increase in the value of the paper and cardboard waste collected in the entire analysed period. The amount of glass waste within the 7 years increased significantly by $844 \mathrm{Mg}$. As in the case of the paper and cardboard waste, the lowest amount occurred in 2011 and this type of waste demonstrated a decrease by $89 \mathrm{Mg}$ in relation to the reference year, with the highest occurring in 2014. Between 2009 and 2014 , there was a significant increase of this fraction of waste by as much as $963 \mathrm{Mg}$, although after 2014, there was a decrease of $119 \mathrm{Mg}$. The plastic waste was characterized by the highest increase of $1.307 \mathrm{Mg}$. As before, the lowest result 


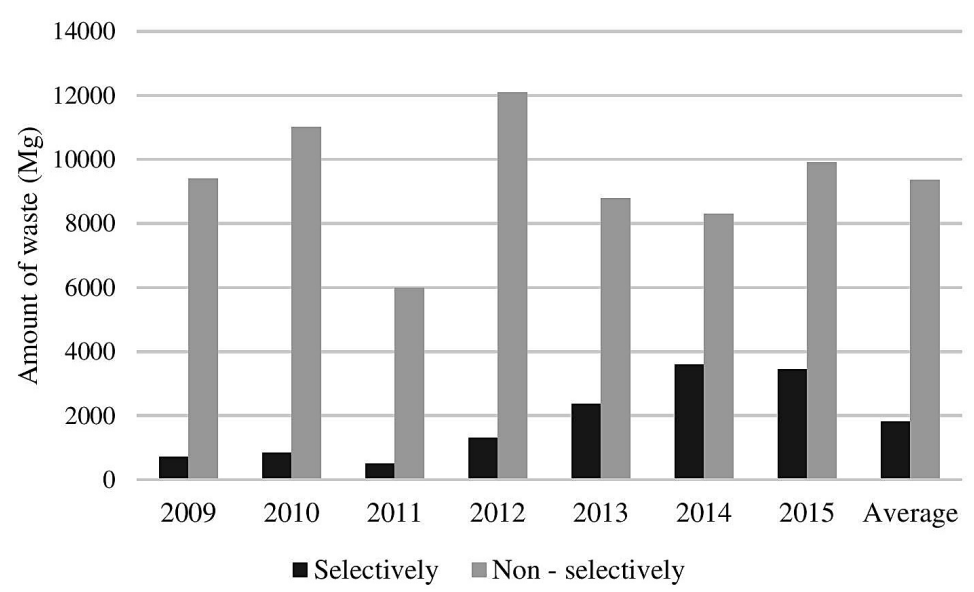

Figure 6. Amount of municipal waste divided into selectively and non-selectively collected

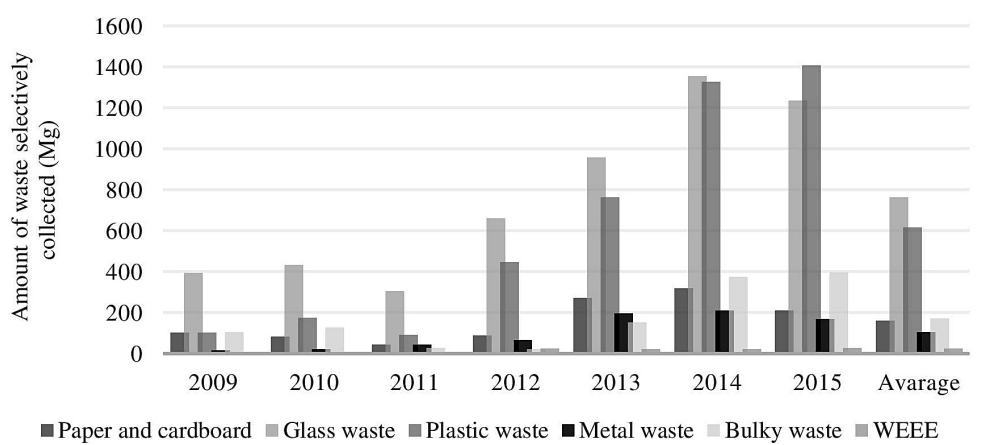

Figure 7. Amount of waste selectively collected according to type

was achieved in 2011, with an amount of $89 \mathrm{Mg}$, while the highest was 1,407 Mg collected in 2015.

The highest average value of this fraction of waste indicates the dominance in the mass of the separately collected waste. The amount of metal waste ranged from $16 \mathrm{Mg}$ in 2009 to $211 \mathrm{Mg}$ in 2014, which demonstrated an increase of $194 \mathrm{Mg}$ with an average of $102.77 \mathrm{Mg}$. A decrease in the amount of this waste by over $40 \mathrm{Mg}$ was also observed between 2014 and 2015. The mass of bulky waste collected has the lowest value at $21 \mathrm{Mg}$ that occurred in 2012, and the highest, at $397 \mathrm{Mg}$, in 2015. Throughout the research period, the mass collection of this type of waste increased by 291 $\mathrm{Mg}$. The amount of WEEE collected in the county in 2012-2015 saw a slight increase of only $3 \mathrm{Mg}$. The lowest result of $22 \mathrm{Mg}$ was achieved in 2013 and 2014, and the highest $25 \mathrm{Mg}$ in 2015, with an average of $23.13 \mathrm{Mg}$. Generally, in the analysed period, an increase in the amount of waste selectively collected by $2,727.2 \mathrm{Mg}$ is noticeable with an average value of $1,822.6 \mathrm{Mg}$.

Figure 8 shows the shares of the six selectively collected waste types. The dominant share is the glass waste $(42 \%)$. The share of plastics waste was lower by $9 \%$. The content of the paper and cardboard as well as bulky waste remained at the same level of $9 \%$. The lowest share was for the metal waste $(6 \%)$ and WEEE (1\%). According to Gidarakos et al. (2006), the composition of the generated waste depends on such factors as demography and geographical determinants.

\section{Waste accumulation ratio}

Figure 9 contains mass rates of general municipal waste and municipal selectively collected waste accumulation per capita per year in 2009-2015. The value of the municipal waste accumulation per capita per year ranged from 81.51 to $103.31 \mathrm{~kg} \cdot \mathrm{cap}^{-1}$ with an average of $87.73 \mathrm{~kg} \cdot \mathrm{cap}^{-1}$, and an accumulation of selectively collected waste from 14.17 to 3.88 $\mathrm{kg} \cdot$ year $^{-1}$ with an average of $9.06 \mathrm{~kg} \cdot$ year $^{-1}$. A significant increase in the value of the first rate was noted in $2009-2012$ by $23.18 \mathrm{~kg}$. In the following years 2013-2015, the increase in the waste accumulation rate was lower and amounted to 


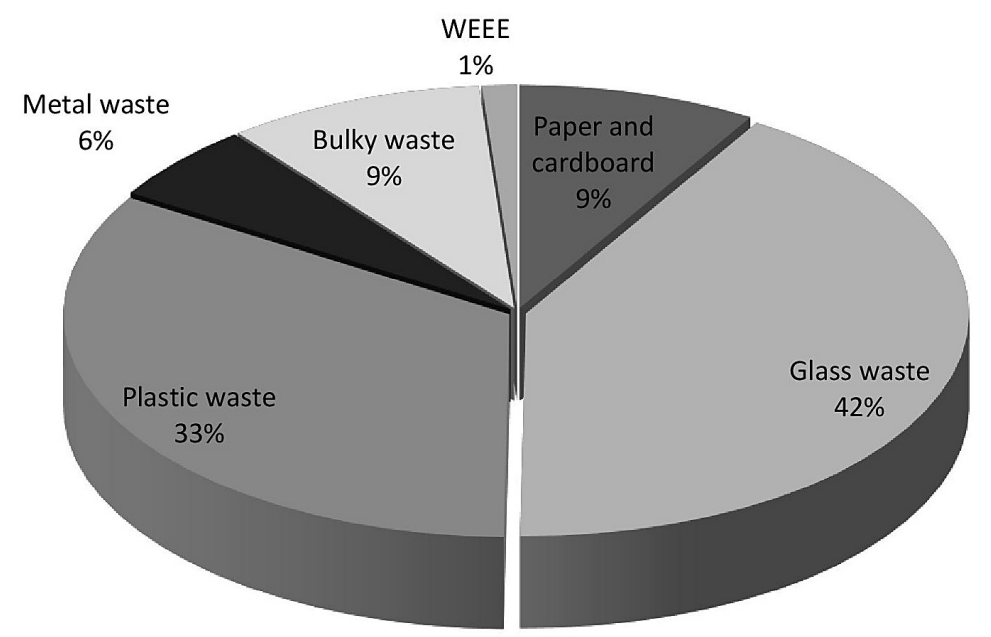

Figure 8. Share of waste selectively collected by type in the county area

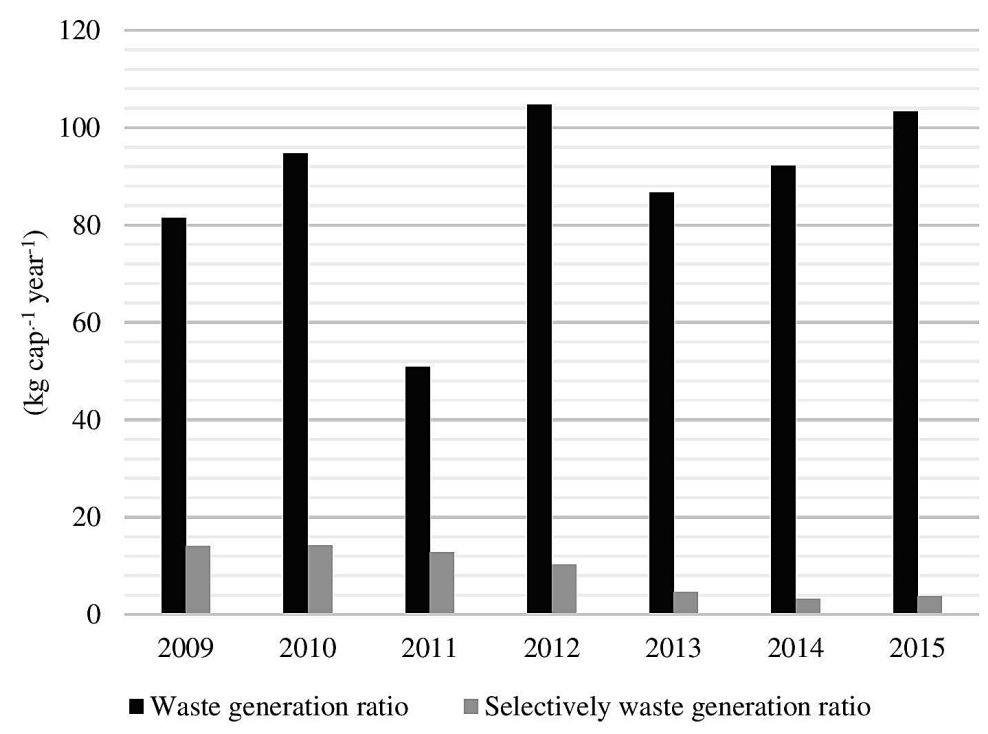

Figure 9. Rate of waste mass accumulation per capita per year

$21.80 \mathrm{~kg}$. The value of the second rate confirmed a decrease by $3.87 \mathrm{~kg}$ and in the following years by $0.84 \mathrm{~kg}$. The lowest value of $50.94 \mathrm{~kg}$ of the first rate occurred in 2011, while the largest was $104.69 \mathrm{~kg}$ in 2012 . The highest result for the second analysed rate occurred in 2010, and the lowest in 2014. The difference in the average values between the general municipal waste accumulation rates and accumulation of selectively collected waste per capita amounted to $78.67 \mathrm{~kg}$. At the same time, an increase in the value of the first rate by $21.80 \mathrm{~kg}$ per capita is noticeable, while the second decreased by $10.29 \mathrm{~kg}$.

Figure 10 shows the mass rates for general municipal waste accumulation per day, which ranged from 0.22 to $0.28 \mathrm{~kg} \cdot \mathrm{cap}^{-1}{ }^{-1}$ with an average of $0.24 \mathrm{~kg} \cdot \mathrm{cap}^{-1}$. Similarly to the analysis of the waste accumulation rates by year, the lowest value of $0.14 \mathrm{~kg}$ and the highest $0.29 \mathrm{~kg}$.per capita occurred in 2011 and 2012, respectively. In the lower value range, the results for the rate of selective waste accumulation per capita per day oscillated between 0.04 and $0.01 \mathrm{~kg}^{-1 a y}{ }^{-1}$ with an average of $0.02 \mathrm{~kg} \cdot \mathrm{day}^{-1}$, which confirms the decline. Such extreme results in relation to the second rate with the lowest value of $0.01 \mathrm{~kg}$ were recorded in 2013-2015, while the highest, at $0.04 \mathrm{~kg}$, occurred in 2009-2011. Between the averages of both rates, a difference of $0.22 \mathrm{~kg}$ is also noticeable. As previously, during the research period there was an increase in the first value, but only by $0.06 \mathrm{~kg}$, while the value of the second rate increased by $0.03 \mathrm{~kg}$ per capita per day. 


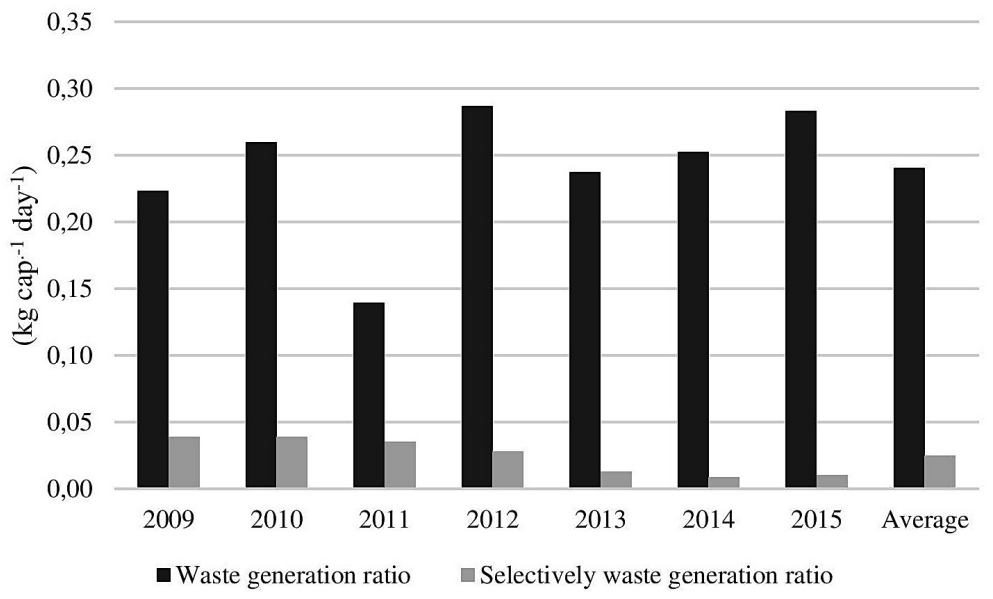

Figure 10. Rate of waste mass accumulation per capita per day

Generally, in the analysed years, an increase in the volume of waste accumulation by $11.51 \mathrm{~kg}$ per capita per year and by $0.03 \mathrm{~kg}$ per capita per day was observed.

\section{DISCUSSION}

The important factors affecting the amount of waste generated include an increase in the number of inhabitants, as well as improvements in the living conditions (Guerrero et al., 2013). The number of inhabitants in the county increased by over 5,000 during the study period and at the same time the amount of collected waste increased by over 3,000 Mg. According to Hannan et al. (2015), an increase in the amount MSW is associated with fast paced urbanisation and population growth. In addition to demography, Imigration may have some impact on the waste management. The achieved result of the external migration predominance was below 70 inhabitants. However, this was insignificant due to the increase in the number of inhabitants of the county, exceeding 5,000. In 2009-2011 there was a decrease in the mass of municipal waste non-selectively collected, exceeding 3,000 Mg. It should be noted that the lowest amounts of collected selectively and non-selectively waste in the same year of 2011 were observed. However, the largest amount of $12,103.6 \mathrm{Mg}$ of collected non-selectively waste occurred in 2012 before the changes in the waste management system. In this year, the number of properties covered by the collection of municipal waste was also the largest.

In general, the increased frequency of waste collection in communes of the county was related to the periods of spring and summer. Similarly, Przydatek et al. (2018) reported an increase in the amount of waste selectively collected in spring. According to Mandl et al. (2008) the waste management efficiency is the result of the optimization of the process, and thus affects the amount of waste collected.

The amount of selectively collected waste in 2011-2014 underwent a nearly 4-fold increase. Moreover, an increase in selectively collected waste was presented by Liikanen et al. (2016). Similarly, there was a significant increase in unemployment by almost $20 \%$ in the county in 2009-2013. Miliute-Plepiene and Plepys (2015) reported that unemployment did not reduce the amount of waste generated. The largest amount of $(3,602 \mathrm{Mg})$ selectively collected waste occurred in 2014, which confirms the improvement in waste management associated with the system changes (Przydatek et al., 2017).

Despite such a significant increase in the amount of selectively collected waste, its share in the total weight of waste constituted only $16 \%$. Such a level of recovery among EU 28 was found in 1995 (Pomberger et al., 2017). A significantly higher percentage of selectively collected waste in rural communes in the mountain areas of Italy was reported by Passarini et al. (Passarini et al., 2011). This confirms the possibility of the impact of regional differences on the efficiency of municipal waste management (Hage and Söderholm, 2008). The highest mass values of paper and cardboard, glass and metal waste suitable for recycling occurred in 2014. In the literature, such growth is regarded as pure profit in relation to landfilling of waste (Nahman, 2010). Glass waste constituted the largest share at $42 \%$. A lower 
percentage of $8 \%$ of this type of waste fraction in an urban commune was reported by Przydatek et al. (2018). The content of paper and cardboard waste was at the level of $9 \%$. The lower content of paper and cardboard in municipal waste by $1.5 \%$ was demonstrated by Dangi et al. (2011).

The low content, at $6 \%$, was the metal waste. The plastic waste experienced the highest increase by $1.307 \mathrm{Mg}$, as well as the highest value of $1.407 \mathrm{Mg}$ over the analysed period, which occurred after the changes. The mass of bulky waste collected in the county with the highest value of $397 \mathrm{Mg}$ occurred in the last examined year. In general, the lowest percentage at $1 \%$ was WEEE, which were collected in a shorter period from 2012 to 2015. In these years, there was a slight increase in the amount of WEEE collected by $3 \mathrm{Mg}$, and the same a dynamic increase in the amount of selectively collected waste, by $2,727.2 \mathrm{Mg}$, was noticeable, as well as a favourable decrease in non-selectively collected waste by $503,9 \mathrm{Mg}$. Additionally, during this period, there was drop in the number of properties subject to regular collection of municipal waste, which was close to 3,000 . It may have been caused by the coverage of a lower number of homes by the waste collection services (Knussen et al., 2014).

The highest value of $104.69 \mathrm{~kg}$ for the municipal waste accumulation rate per capita per year occurred before the changes in waste management and was much higher than that reported by Dahlen et al. (2007) in Sweden. However, the average value of this rate was more than 4 times lower than the average value of $475 \mathrm{~kg}$ per capita for the European Union (Eurostat, 2016). The highest value of the $0.29 \mathrm{~kg}$ rate of selective waste accumulation per capita daily occurred in 2012 and was significantly lower than the demonstrated $2.2 \mathrm{~kg}$ and $0.3-1 \mathrm{~kg}$ per capita daily by Kamaruddin et al. (2017) and Dangi et al. (2011), respectively. However, the highest value of this rate at $0.04 \mathrm{~kg}$ and the lowest at $0.01 \mathrm{~kg}$ per day, covered the 3 years before the changes (2009-2011) and practically after the changes (2013-2015), respectively. The highest registered unemployment rate of 10.569 occurred in 2013. According to Abdoli et al. (2011), unemployment plays an important role in the production of municipal solid waste. The average values of the amount of general municipal waste accumulation rates per capita were higher than the average values of selectively collected waste accumulation rates per capita of by $84.43 \mathrm{~kg}$ per year and
$0.22 \mathrm{~kg}$ per day, respectively. The latter result as a difference was higher by $0.07 \mathrm{~kg}$ than the value of the rate reported in Algeria by Garfě et al. (2009). In this case, these rates differ significantly, which confirms the need for increased ecological awareness (Chan, 2008; Ekere et al., 2009). According to Matsakas et al. (2017) the accumulation of waste should be raised to public awareness due to problems caused by the growing amount of waste in the environment. In general, there is a noticeable increase in the value of waste accumulation by more than $10 \mathrm{~kg}$ per capita per year and by $0.03 \mathrm{~kg}$ per capita per day, throughout the entire research cycle. Matsumoto (2011) and Manaf and Samah (2009) reported an increase in the value of the accumulation rate together with an increase in the number of inhabitants. Daskalopoulos et al. [40], based on the conducted research, presented that the differences in the accumulation of waste may also be the result of various consumer behaviours.

\section{CONCLUSIONS}

On the basis of the analysis of the research material concerning the Limanowa County in the mountains region, the following conclusions can be drawn:

- The number of inhabitants in the county increased by $4 \%$ with a simultaneous increase in the amount of municipal waste generated by $32 \%$ and a decrease in registered unemployment by $15 \%$.

- The largest amount of non-selectively collected waste and at the same time, the number of properties covered by collection of municipal waste occurred before the changes in waste management.

- The highest mass of selectively collected waste occurred after system changes in waste management.

- In the period 2012-2015, there was a dynamic increase in the amount of selectively collected waste by almost $3,000 \mathrm{Mg}$, and a favourable fall in non-selectively collected waste by over $500 \mathrm{Mg}$, at the drop in the number of properties covered by organized collection of municipal waste by approximately 3,000 .

- In the mass of municipal collected waste, a low percentage not exceeding $20 \%$ was attributable to selectively collected waste with the highest share of glass waste at over $40 \%$. 
- The average values of municipal waste accumulation rates per capita were higher than the average values of accumulation of waste selectively collected by $84.43 \mathrm{~kg}$ per year and $0.22 \mathrm{~kg}$ per day, which indicates the need for an increase of ecological awareness.

- Generally, in the whole research cycle an increase in the value of waste mass accumulation per capita is noticeable by over $10 \mathrm{~kg}$ per year and by $0.03 \mathrm{~kg}$ per day.

- The results obtained confirmed the noticeable impact of the implementation of the provisions of Directive 1999/31/WE and Directive 2008/98/EC into Polish legislation through the increase in municipal waste recovery.

\section{Acknowledgments}

I would like to thank the authorities of the 12 communes of the Limanowa County (Poland) for all the help and access to the materials and information necessary to develop the article.

\section{REFERENCES}

1. Faroog M., Meraj G. 2016 Solid waste management in Jammu. J\&K Envis Newsletter. 3(4)

2. Burnley SJ 2007 A review of municipal solid waste composition in the United Kingdom. Waste Management 27:1274-1285

3. Buenrostro O., Bocco G. 2001 Urban solid waste generation and disposal in Mexico: a case study, Waste Management \& Research 19(2):169-76

4. Directive 1999/31/EC of 26 April 1999 on the landfill of waste (WE L 182 16.07.1999) https://eur-lex.europa.eu/legal-content/EN/ TXT/?uri=celex\%3A31999L0031 accessed 20.01.2019

5. Directive 2008/98/EC of the European Parliament and of the Council of 19 November 2008 on waste and repealing certain Directives (L 312/3 from 2008) see http://eur-lex.europa.eu/legal-content/ EN/TXT/?uri=celex\%3A32008L0098/ accessed 20.05.2018

6. Boas-Berg A., Radziemska M., Adamcová D., Zloch J., Vaverková M.D. 2018 Assessment Strategies for Municipal Selective Waste Collection Regional Waste Management. Journal of Ecological Engineering, Vol. 19, No 1:33-41

7. Pomberger R., Sarc R., Lorber K.E. 2017 Dynamic visualisation of municipal waste management performance in the EU using Ternary Diagram method. Waste Management 61, 558-571
8. Gharfalkar M., Campbell C., Ali Z., Hillier G. 2015 Analysis of waste hierarchy in the European waste directive 2008/98/EC, Waste management, Volume 39, 305-313

9. Hekkert M.P., Joosten L.A.J., Worrell E. 2000 Analysis of the paper and wood flow in the Netherlands. Resour. Conserv. Recycl. 30: 29-48

10. Miliute-Plepiene J., Plepys A. 2015 Does food sorting prevents and improves sorting of household waste? A case in Sweden. Journal of Cleaner Production. 101: 182-192

11. Talalaj I.A., Walery M. 2015 The effect of gender and age structure on municipal waste generation in Poland. Waste Management 40:3-8

12. Liikanen M., Sahimaa O., Hupponen M., Havukainen J., Sorvari J., Horttanainen M. 2016 Updating and testing of a finnish method for mixed municipal solid waste composition Studies. Waste Management 52:25-33

13. Kaseva M.E., Moirana J.L. 2010 Problems of solid waste management on Mount Kilimanjaro: a challenge to tourism, Waste Management \& Researche 28(8):695-704

14. Özbay I. 2015 Evaluation of Municipal Solid Waste Management Practices for an Industrialized City. Pol. J. Environ. Stud. Vol. 24, No. 2:637-644

15. Matsakas L, Gao Q, Jansson S., Rova U., Christakopoulos P. 2017 Green conversion of municipal solid wastes into fuels and chemicals. Electronic Journal of Biotechnology 26:69-83

16. Philippe F., Culot M. 2009 Household solid waste generation and characteristics in Cape Haitian city, Republic of Haiti. Resources, Conservation and Recycling 54: 73-78

17. Guerrero L.A., Maas G., Hogland W. 2013 Solid waste management challenges for cities in developing countries. Waste Management 33: 220-232

18. Noori R., Abdoli M.A., Ghazizade M.J., Samieifard R (2009) Comparison of neural network and principal component-regression analysis to predict the solid waste generation in Tehran. Iranian Journal of Public Health, Volume 38, Issue 1: 74-84

19. Den Boer E., Jędrczak A., Kowalski Z., Kulczycka J., Szpadt, R. 2010 A review of municipal solid waste composition and quantities in Poland. Waste Management 30:369-377

20. Statistics Poland 2009-2016 https://bdl.stat.gov.pl accessed 5.06.2018.

21. Przydatek G., Kochanek A., Basta M. 2017 Analysis of changes in municipal waste management at the county level, Journal of Ecological Engineering, Volume 18, Issue 1:72-80

22. De Oliveira Simonetto E., Borenstein D. 2009 A decision support system for the operational planning of solid waste collection. Waste Manage. 27:1286-1297 
23. Gidarakos E., Havas G., Ntzamilis P. 2006) Municipal solid waste composition determination supporting the in tegrated solid waste management system in the Island of Crete. Waste Management 26:668-679

24. Hannan M.A., Al Mamun M.A., Hussain A., Basri H., Begum R.A. 2015 A review on technologies and their usage in solid waste monitoring and management systems: issues and challenges. Waste Manag 4:509-523

25. Przydatek G., Kostrzewa K., Kaminska D. 2018 An Analysis of Municipal Waste Management in a Selected Urban Municipality on the Basis of Selectively Collection Renewable Energy Sources: Engineering, Technology, Innovation: ICORES. 473-482

26. Mandl U., Direx A., Iskovitz F. 2008 The effectiveness and efficiency of public spending economic paper. 301. Economic Commission Brussels; Directorate General Economic and Monetary Affairs, ISBN 978-92-79-08226-9, 1-34

27. Passarini F., Vassura I., Monti F., Morselli L., Villani B. 2011 Rates of waste management efficiency related to different territorial conditions. Waste Management 31 (4):785-792

28. Hage O., Söderholm P. 2008 An econometric analysis of regional differences in household waste collection: the case of plastic packaging waste in Sweden. Waste Manage. 28:1720-1731

29. Nahman A. 2010 Extended producer responsibility for packaging waste in South Africa: Current approaches and lessons learned. Resources, Conservation and Recycling 54:155-162

30. Dangi M.B., Pretz C.R., Urynowicz M.A., Gerow K.G., Reddy J.M. 2011 Municipal solid waste generation in Kathmandu, Nepal, Journal of Environmental Management 92:240-249

31. Knussen Ch., Yule F., MacKenzie J., Wells M. 2004 An analysis of intentions to recycle household waste: The roles of past behaviour, perceived habit, and perceived lack of facilities. Journal of Environmental Psychology 24:237-246
32. Dahlén L., Vukicevic S., Meijer J.E., Lagerkvist A. 2007 Comparison of different collection systems for sorted household waste in Sweden. Waste Management 27:1298-1305

33. Eurostat European Commission - Eurostat (2016) see http://ec.europa.eu/eurostat/ statistics-explained/index.php/Municipal_waste_statistics accessed 20.06.2018.

34. Kamaruddin M.A., Yusoff M.S., Rui L.M., Isa A.M., Zawawi M.H., Alrozi R. 2017 An overview of municipal solid waste management and landfills leachate treatment: Malaysia and Asian perspectives. doi 10.1007/s11356-017-0303-9

35. Abdoli M.A., Falahnezhad M., Behboudian S. 2011 Multivariate econometric approach for solid waste generation modeling: impact of climate factors, Environ. Eng. Sci. 28 (9) see https://doi. org/10.1089/ees.2010.0234

36. Garfě M., Tondelli S., Bonoli A. 2009 Multicriteria decision analysis for waste management in Saharawi refugee camps. Waste Management 29:2729-2739

37. Chan K. 1998 Mass communication and proenvironmental behaviour: waste recycling in Hong. Kong. Journal of Environmental Management 52:317-325

38. Ekere W., Mugisha J., Drake L. 2009 Factors influencing waste separation and utilization among household in the Lake Victoria crescent, Uganda. Waste Management 29:3047-3051

39. Matsumoto S. 2011 Waste separation at home: Are Japanese municipal curbside recycling policies efficient?, Resources Conservation and Recycling 55:325-334

40. Manaf L.A., Samah M.A.A., NIM Z. 2009 Municipal solid waste management in Malaysia: Practices and challenges. Waste Manag 29:2902-2906

41. Daskalopoulos E., Badr O., Probert S.D. 1998 Municipal solid waste: a prediction methodology for the generation rate and composition in the $\mathrm{Eu}-$ ropean Union countries and the United states of America. Resour. Conserv. Recycl 24:155-166. 